\title{
THE STUDY OF THE COMPLEXATION OF CALIX[4]ARENE AND CALIX[4]RESORCINARENE WITH RESIN ACIDS BY THE RP HPLC METHOD. BINDING CONSTANTS DETERMINATION
}

\author{
O.I.Kalchenko, S.O.Cherenok, A.V.Solovyov*, V.V.Gorbatchuk**, \\ S.Yu.Suikov, V.I.Kalchenko \\ Institute of Organic Chemistry, National Academy of Sciences of Ukraine \\ Murmanska str., 5, Kyiv-94, 02660, Ukraine \\ * Department of Chemical and Biomolecular Engineering, University of California \\ **Kazan Federal University, Russian Federation
}

Key words: calix[4]arenes; resin acids; reversed-phase high performance liquid chromatography; inclusion complexes; binding constants; molecular modelling

The Host-Guest complexation of octakis-(diphenoxyphosphoryloxy)tetramethylcalix[4]resorcinarene (CR) and 5,17-bis-(N-tolyliminomethyl)-25,27-dipropoxycalix[4]arene (CA) with 6 diterpenoid (resin) acids has been studied by the reversed phase high-performance liquid chromatography (RP HPLC). The chromatographic characteristics (retention time $t_{R}$ and retention factor $k^{\prime}$ ) of resin acids have been determined. The lipophilicity values log $P$ of the acids, binding constants $K_{A}$ (395-682 $\mathrm{M}^{-1}$ for $C R$ and 844-1268 $\mathrm{M}^{-1}$ for CA), as well as Gibbs free energies $\Delta G(-14.79--16.14 \mathrm{~kJ} / \mathrm{mol}$ for $C R$ and $-16.70--17.67 \mathrm{~kJ} / \mathrm{mol}$ for $C A)$ of the complexes with resin acids have been calculated. Molecular modelling of CA complexes has revealed the presence of hydrogen bonds between carboxylic groups of acids and nitrogen atoms of imino groups at the upper rim or oxygen atoms of the hydroxyl groups at the lower rim of the CA macrocycle. Molecular modelling of CR complexes has shown the presence of hydrogen bonds between carboxylic groups of acids and oxygen atoms of diphenoxyphosphoryloxy groups at the upper rim of the CR macrocycle. The effect of $\log P$ values on $K_{A}$ values of the CR/CA complexes has been assessed. The linear dependence of the binding constants on the acid lipophilicity indicates a significant role of solvophobic interactions on the complexation. The relationship between supramolecular $\left(K_{A}\right)$ and physicochemical (log $P, p K a)$ characteristics of acids has been determined.

ДОСЛІДЖЕННЯ КОМПЛЕКСОУТВОРЕННЯ КАЛІКС[4]АРЕНУ ТА КАЛІКС[4]РЕЗОРЦИНАРЕНУ ІЗ СМОЛЯНИМИ КИСЛОТАМИ МЕТОДОМ ОФ ВЕРХ. ВИЗНАЧЕННЯ КОНСТАНТ ЗВ'ЯЗУВАННЯ

О.І.Кальченко, С.О.Черенок, А.В.Соловйов, В.В.Горбачук, С.Ю.Суйков, В.І.Кальченко

Ключові слова: калікс[4]арени; смоляні кислоти; обернено-фразна високоефективна рідинна хроматографрія; комплекси включення; константи зв'язування; молекулярне моделювання

Комплексоутворення типу Гість-Господар октакіс-(дифреноксифосффорилокси)-тетраметилкалікс[4]резорцинарену (CR) та 5,17-біс-(N-толілімінометил)-25,27-дипропоксикалікс[4]арену (CA) з 6 дитерпеноїдними (смоляними) кислотами було досліджено методом обернено-фразної високоефективної рідинної хроматографрії (ОФ ВЕРХ). Визначені хроматографрічні характеристики (час утримання $t_{R}$ та фрактор утримання k') смоляних кислот. Розраховано значення ліпофільності log Р смоляних кислот та констант зв'язування $K_{4}$ комплексів (395-682 $\mathrm{M}^{-1}$ для CR ma 844-1268 $\mathrm{M}^{-1}$ для CA), а також значення вільних енергій Гіббса $\Delta \mathrm{G} \mathrm{(-14.79} \mathrm{-} \mathrm{-16.14} \mathrm{кДж/моль} \mathrm{для} \mathrm{CR} \mathrm{ma} \mathrm{-16.70} \mathrm{-} \mathrm{-17.67} \mathrm{кДж/моль} \mathrm{для} \mathrm{CA)} \mathrm{із} \mathrm{смоляними} \mathrm{кислотами.}$ Молекулярне моделювання комплексів СА вказало на присутність водневих зв'язків між карбоксильними групами кислот та атомами азоту іміно-груп верхнього вінця СА макроцилу або атомами кисню ОН груп його нижнього віния. Молекулярне моделювання комплексів CR вказало на присутність водневих зв'язків між карбоксильними групами кислот та атомами кисню дифеноксифоосфорилокси-груп верхнього віния макроциклу CR. Здійснено оцінку впливу $\log P$ на константи зв'язування $K_{\text {A }}$ комплексів CR/CA. Лінійна залежність $K_{A}$ від $\log P$ кислот вказує на роль сольвофобних взаємодій на комплексоутворення. Встановлено взаємозв'язок між супрамолекулярними $\left(K_{A}\right)$ та фрізико-хімічними (log $P$, pKa) характеристиками кислот.

\section{ИССЛЕДОВАНИЕ КОМПЛЕКСООБРАЗОВАНИЯ КАЛИКС [4]АРЕНА И КАЛИКС[4]РЕЗОРЦИНАРЕНА} СО СМОЛЯНЫМИ КИСЛОТАМИ МЕТОДОМ ОФ ВЭЖХ. ОПРЕДЕЛЕНИЕ КОНСТАНТ СВЯЗЫВАНИЯ О.И.Кальченко, С.А.Черенок, А.В.Соловйов, В.В.Горбачук, С.Ю.Суйков, В.И.Кальченко

Ключевые слова: каликс[4]арены; смоляные кислоты; обращенно-фразная высокоэффрективная жидкостная хроматография; комплексы включения; константы связывания; молекулярное моделирование Комплексообразование типа Гость-Хозяин октакис-(дифреноксифосфрорилокси)-тетраэтилкаликс[4]резорцинарена (CR) и 5,17-бис-(N-толилиминометил)-25,27-дипропоксикаликс[4]арена (CA) с 6 дитерпеноидными ( смоляными) кислотами было исследовано методом обращенно-фразной высокоэффрективной жидкостной хроматографии (ОФ ВЭЖХ). Определены хроматографические характеристики (время удерживания $t_{R}$ и фрактор удерживания $\left.k^{\prime}\right)$ смоляных кислот. Рассчитаны значения липофильности log $P$ смоляных кислот и констант связывания $K_{\mathrm{A}}$ их комплексов (395-682 $\mathrm{M}^{-1}$ для CR и 844-1268 $\mathrm{M}^{-1}$ для CA), а также значения свободных энергий Гиббса $\Delta G$ (-14.79 - -16.14 кДж/моль для CR и -16.70 - -17.67 кДж/моль для CAL) со смоляными кислотами. Молекулярное моделирование комплексов CA показало наличие водородных связей между карбоксильными группами кислот и атомами азота имино-групп верхнего обода 
макроцикла СА или атомами кислорода гидроксильных групп его нижнего обода. Молекулярное моделирование комплексов CR показало наличие водородных связей между карбоксильными группами кислот и атомами кислорода дифреноксифосфрорилокси-групп верхнего обода макроцикла CR. Оценено влияние $\log P$ на константы связывания $K_{A}$ комплексов CR/CA. Линейная зависимость $K_{A}$ om log $P$ кислот свидетельствует о влиянии сольвофробных взаимодействий на процесс комплексообразования. Установлена взаимосвязь между супрамолекулярными $\left(K_{A}\right)$ и фризико-химическими (log $\left.P, p K a\right)$ характеристиками кислот.

Naturally occurring di- and triterpenoid acids are isolated from different plant sources [1], have a wide variety of biological activities [2-9], and generate considerable interest in the pharmacological community. These compounds play an important role in searching new drugs for the treatment of different diseases. It is well known that abietic acid and abietane diterpenoids have the anti-inflammatory [10], phytoalexinlike [11], and anticonvulsant activities [12]. In the work [13] the antiviral activity against HHV-1 and HHV-2 for abietic and dehydroabietic acid was evaluated in vitro. Methyl abietate, abietinal, abietadienoic acid, methyl abietadienoate, abietadienol and dehydroabietinol acetate showed a significant anti-herpetic activity. Maleopimaric acid and its imide revealed the bacterial, fungicidal and nematocidal properties [14]. In the work [15] the antiulcer activity of quinopimaric acid was described.

Pentacyclic triterpenes - betulin, betulinic, oleanolic and ursolic acids possess the anticancer, anti-inflammatory and antiviral activity. Unfortunately, the biological activity of these compounds is reduced by their poor solubility or bioavailability. To improve these properties the supramolecular Host-Guest complexes of betulinic acid, ursolic acid $\left(\mathrm{K}_{\mathrm{A}} 140 \mathrm{M}^{-1}\right)$ or oleanolic acid $\left(\mathrm{K}_{\mathrm{A}} 145 \mathrm{M}^{-1}\right)$ with cyclodextrins were prepared and studied [16-18].

Along with cyclodextrins, calixarenes [19] are one of the most important categories of the supramole-

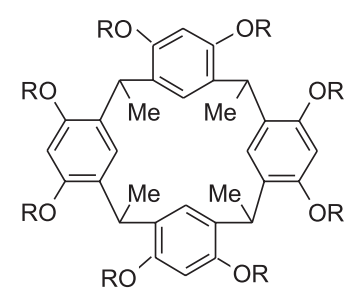

$\mathrm{R}=\mathrm{P}(\mathrm{O})(\mathrm{OPh})_{2}$ cular Hosts for application in pharmacology [20-22] Compared to cyclodextrins, calixarenes exhibit a high degree of chemical functionalization, which leads to obtaining compounds with interesting physicochemical and binding properties. There are many conformational isomers of calixarenes, and a large number of cavities of different sizes and shapes, which can be involved in molecular recognition and binding processes.

Formerly it was shown that octakis(diphenoxyphosphoryloxy)calix[4]resorcinarene (CR) and bisiminocalix[4] arene (CA) appeared to be effective complexing agents for aromatic hydrocarbons [23], benzene carboxylic acids $[24,25]$, pyridine carboxylic acids [26] and 2,4-dichlorophenoxyacetic acid [27].

In this work for the first time the complexation $\mathbf{C R}$ and CA with 6 diterpenoid resin acids - pimaric 1, maleopimaric 2, palustric 3, dehydroabietic $\mathbf{4}$, abietic $\mathbf{5}$ and neoabietic $\mathbf{6}$ (Guest molecules) (Fig. 1) in watercontaining solutions was studied, and stability constants of their supramolecular Host-Guest complexes were determined by the RP HPLC method. To the best of our knowledge, no complexation of any calixarenes with diand triterpenoid acids was described in literature.

We believe that the study of the complexation of CA and $\mathbf{C R}$ with resin acids may be useful for understanding of the process of recognition and binding of diterpenoids in the aqueous medium. The results obtained can be used for developing drug delivery systems for these biologically active acids.

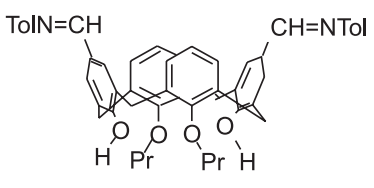

\section{CR}

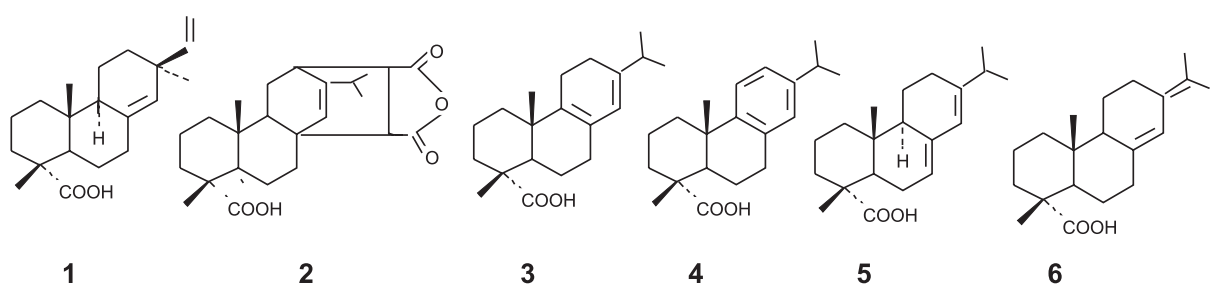

Fig. 1. Structural formulas of calix[4]resorcinarene CR, calix[4]arene CA (Hosts) and pimaric 1, maleopimaric 2, palustric 3, dehydroabietic 4, abietic 5, neoabietic 6 acids (Guest). 


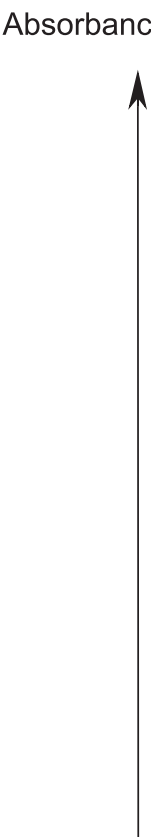

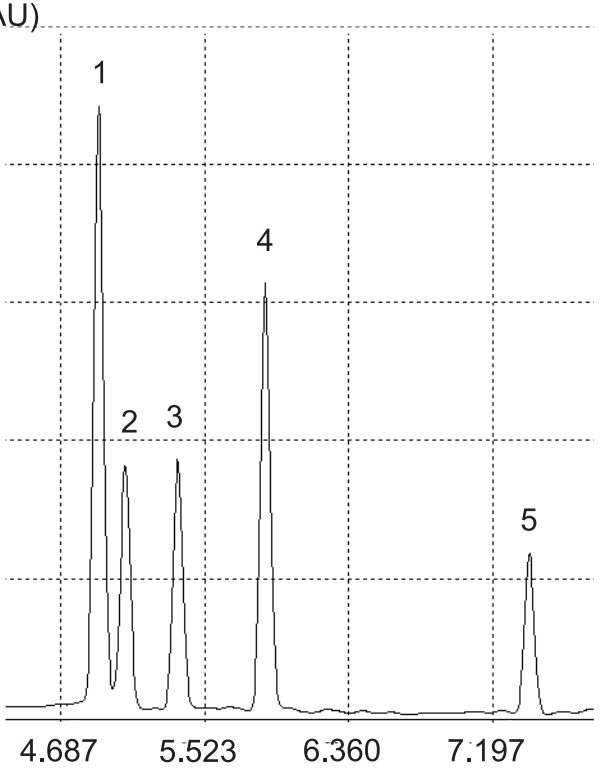

a

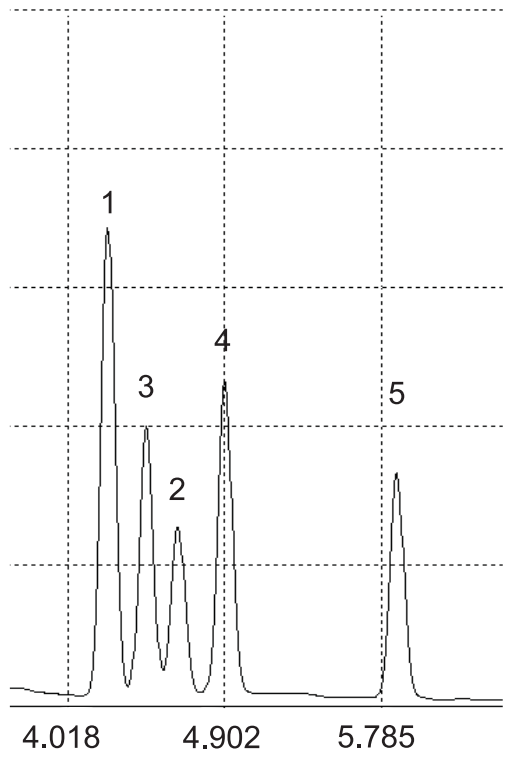

b

Fig. 2. Chromatograms of resin acids before (a) and after (b) CR addition to the mobile phase. Resin acids: $\mathbf{1}$ - pimaric; $\mathbf{2}$ - maleopimaric; $\mathbf{3}$ - palustric; $\mathbf{4}$ - dehydroabietic; $\mathbf{5}$ - abietic.

\section{Results and Discussion}

The CR/CA were registered on the chromatograms by sharp peaks with retention factors $\mathrm{k}^{\prime} 8.65$ (CR) and 0.89 (CA). Chromatograms of the resin acids obtained before and after $\mathbf{C R}$ and CA addition in the mobile phase are presented in Fig. 2, 3.

Absorbance (mAU)

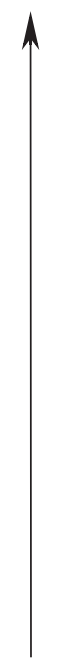

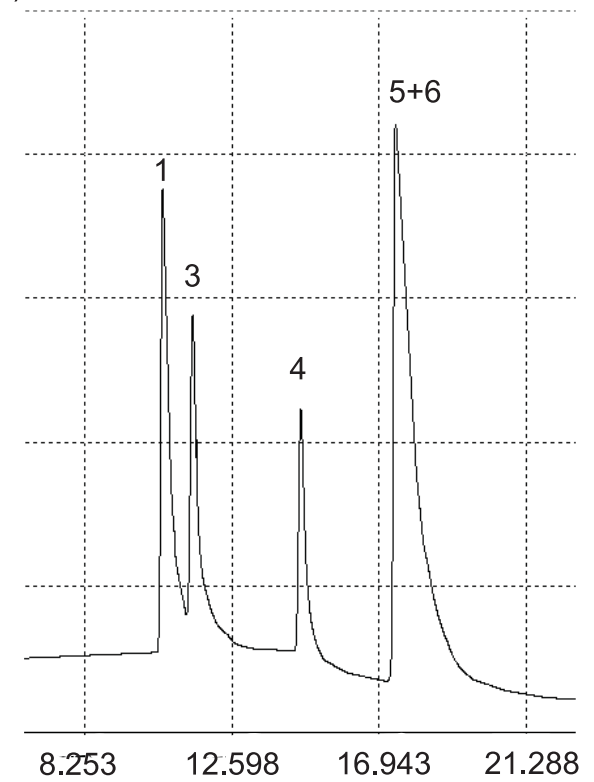

a
A comparative estimation of the chromatograms presented in Fig. 2, 3 shows that $\mathbf{C R}$ and $\mathbf{C A}$ addition to the mobile phase decreases the retention times and changes the elution order of acids. It should be noted CA addition allows separating abietic $\mathbf{5}$ and neoabietic 6 acids (Fig. 3). Formation of the Host-Guest inclusion complexes weakens the interaction of these
3

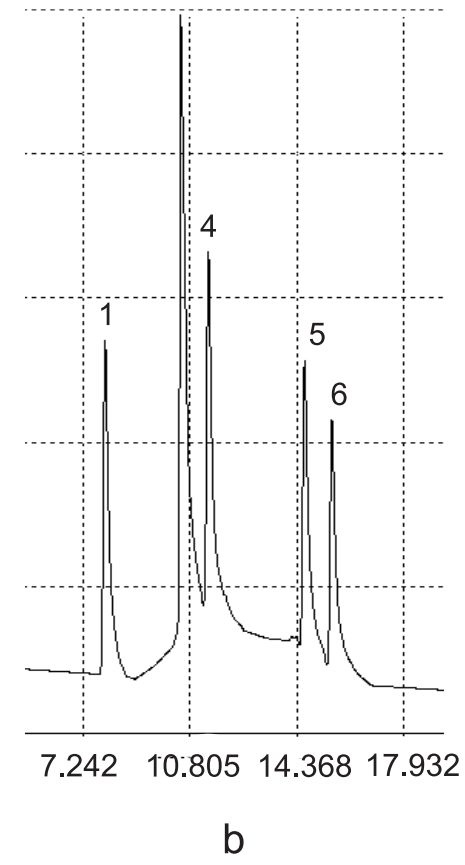

Fig. 3. Chromatograms of resin acids before (a) and after (b) CA addition to the mobile phase. Resin acids: 1 - pimaric; 3 - palustric; 4 - dehydroabietic; 5 - abietic; 6 - neoabietic. 
Table 1

Retention factors $\mathrm{k}^{\prime}$ of resin acids $\mathbf{1 - 6}$ determined before and after CR/CA addition

\begin{tabular}{|l|c|c|c|c|}
\hline \multirow{2}{*}{ Resin acid } & \multicolumn{4}{|c|}{ Retention factor, $\mathrm{k}^{\prime}$ (RSD = 3-5\%) } \\
\cline { 2 - 5 } & $\begin{array}{c}\text { Before CA } \\
\text { addition }\end{array}$ & $\begin{array}{c}\text { After CA } \\
\text { addition }\end{array}$ & $\begin{array}{c}\text { Before } \\
\text { CR } \\
\text { addition }\end{array}$ & $\begin{array}{c}\text { After CR } \\
\text { addition }\end{array}$ \\
\hline Pimaric & 10.17 & 7.38 & 3.80 & 3.17 \\
\hline Maleopimaric & 12.21 & 8.91 & 4.66 & 4.0 \\
\hline Palustric & 12.29 & 8.67 & 4.71 & 3.76 \\
\hline Dehydroabietic & 13.38 & 9.79 & 5.17 & 3.41 \\
\hline Abietic & 17.22 & 12.67 & 6.83 & 5.26 \\
\hline Neoabietic & 19.18 & 14.40 & 7.66 & 5.63 \\
\hline
\end{tabular}

acids with the stationary phase in the RP HPLC conditions. The linear character of $1 / k^{\prime} v s$ plots on the calixarene concentration $(\mathrm{r}=0.99)$ indicates formation of the Host-Guest supramolecular complexes with 1:1 stoichiometry. The retention factors $k^{\prime}$ of acids 1-6 obtained before and after addition of $\mathbf{C R}$ and $\mathbf{C A}$ to the mobile phase are presented in Tab. 1.

The binding constants $K_{A}$ and free Gibbs energies $\Delta G\left(\Delta G=-R T \ln K_{A}\right)$ of the Host-Guest calixarene complexes with the acid molecules were calculated by the method described in and are presented in Tab. 2.

As shown in Tab. 2, the binding constants $K_{A}$ of resin acids 1-6 are in the range of 395-682 $\mathrm{M}^{-1}$ for CR complexes and 844-1268 $\mathrm{M}^{-1}$ for $\mathbf{C A}$ complexes. The complexes of resin acids can be stabilized by different supramolecular interactions (hydrogen bonds, van der Waals, solvophobic interaction, etc.). Therefore, the
The values of $K_{A}\left(\mathrm{M}^{-1}\right)$ and $\Delta G(\mathrm{~kJ} / \mathrm{mol})$ of the calixarene complexes with resin acids 1-6

\begin{tabular}{|l|c|c|c|c|}
\hline \multirow{3}{*}{ Resin acid } & \multicolumn{2}{c|}{ CR } & \multicolumn{2}{c|}{ CA } \\
\cline { 2 - 5 } & $K_{A}(\overline{\mathrm{A}} \pm s)$ & $\Delta G$ & $K_{A}(\overline{\mathrm{A}} \pm s)$ & $\Delta G$ \\
\hline Pimaric & $395 \pm 71$ & -14.79 & $1268 \pm 228$ & -17.67 \\
\hline Maleopimaric & $548 \pm 80$ & -15.60 & $1102 \pm 176$ & -17.33 \\
\hline Palustric & $464 \pm 66$ & -15.19 & $1121 \pm 157$ & -17.37 \\
\hline Dehydroabietic & $640 \pm 95$ & -15.98 & $1158 \pm 174$ & -17.45 \\
\hline Abietic & $557 \pm 82$ & -15.64 & $862 \pm 121$ & -16.72 \\
\hline Neoabietic & $682 \pm 102$ & -16.14 & $844 \pm 135$ & -16.70 \\
\hline
\end{tabular}

role of hydrophobic interactions for the complexes is confirmed by the binding constants correlation with $\log P$ of resin acids (Fig. 4, 5).

Increase of the $\log P$ values of acids increases the $K_{A}$ values of their complexes with CR (Fig. 4), but decreases $K_{A}$ values for the complexes with CA (Fig. 5).

To clarify the nature of supramolecular interactions the molecular modelling of CA and CR complexes with resin acids were carried out. The Host-Guest complexation with CA is presented in Fig. 6.

As shown in Fig. 6A-6F, all resin acids are included into the macrocyclic cavity of CA. The inclusion of HostGuest complexes is stabilized by different supramolecular interactions, first of all, hydrogen bonds. In the complexes shown in Fig. 6A, 6C and 6D the hydroxyl group of pimaric, abietic and neoabietic acids, respectively, form hydrogen bonds with a basic nitrogen atom

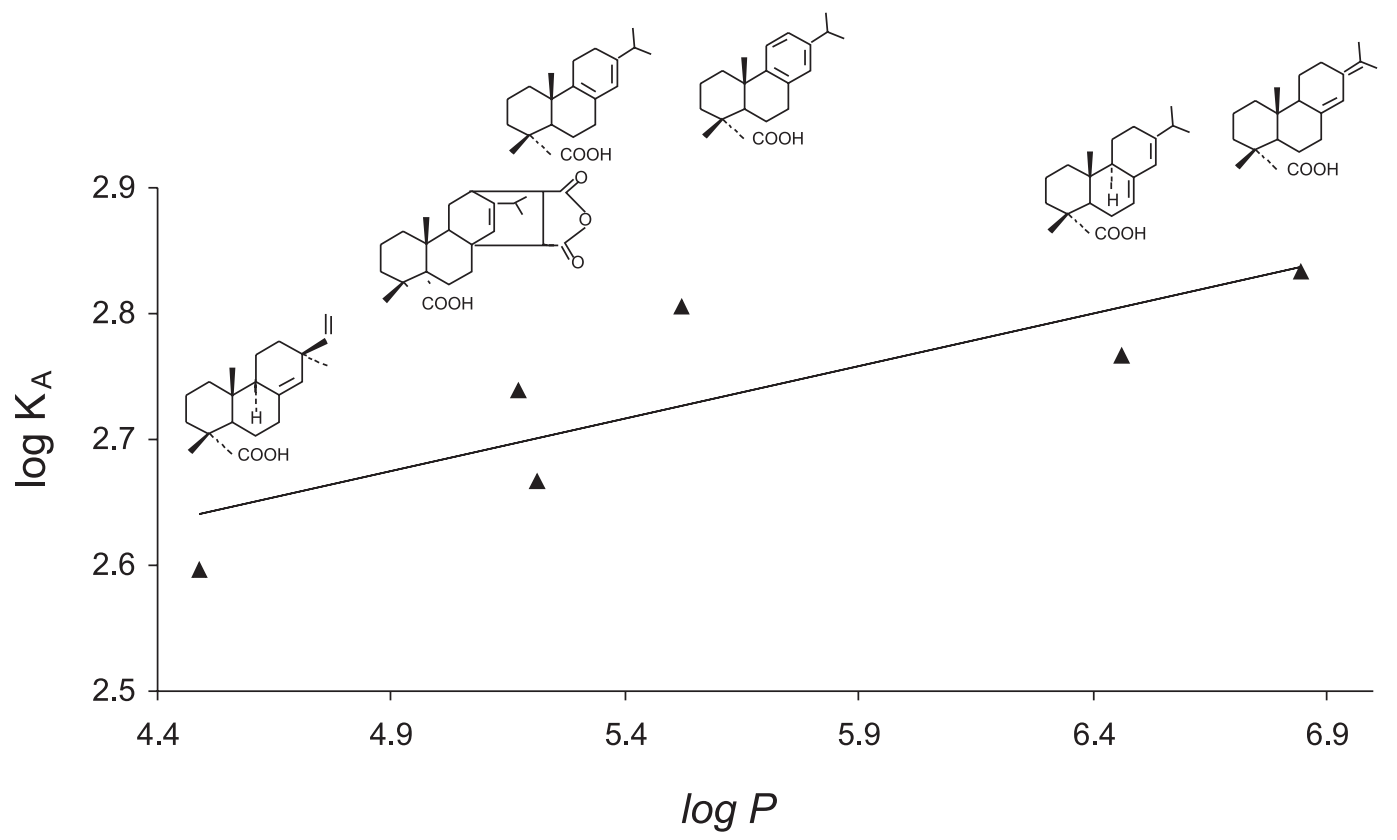

Fig. 4. The plot of $\log K_{A} v s \log P$ for $C R$ complexes with pimaric 1, maleopimaric 2, palustric 3 , dehydroabietic 4 , abietic 5 , neoabietic 6 acids (the relationship described this correlation is: $y=0.0835 x+2.2658 ; r=0.83$ ). 


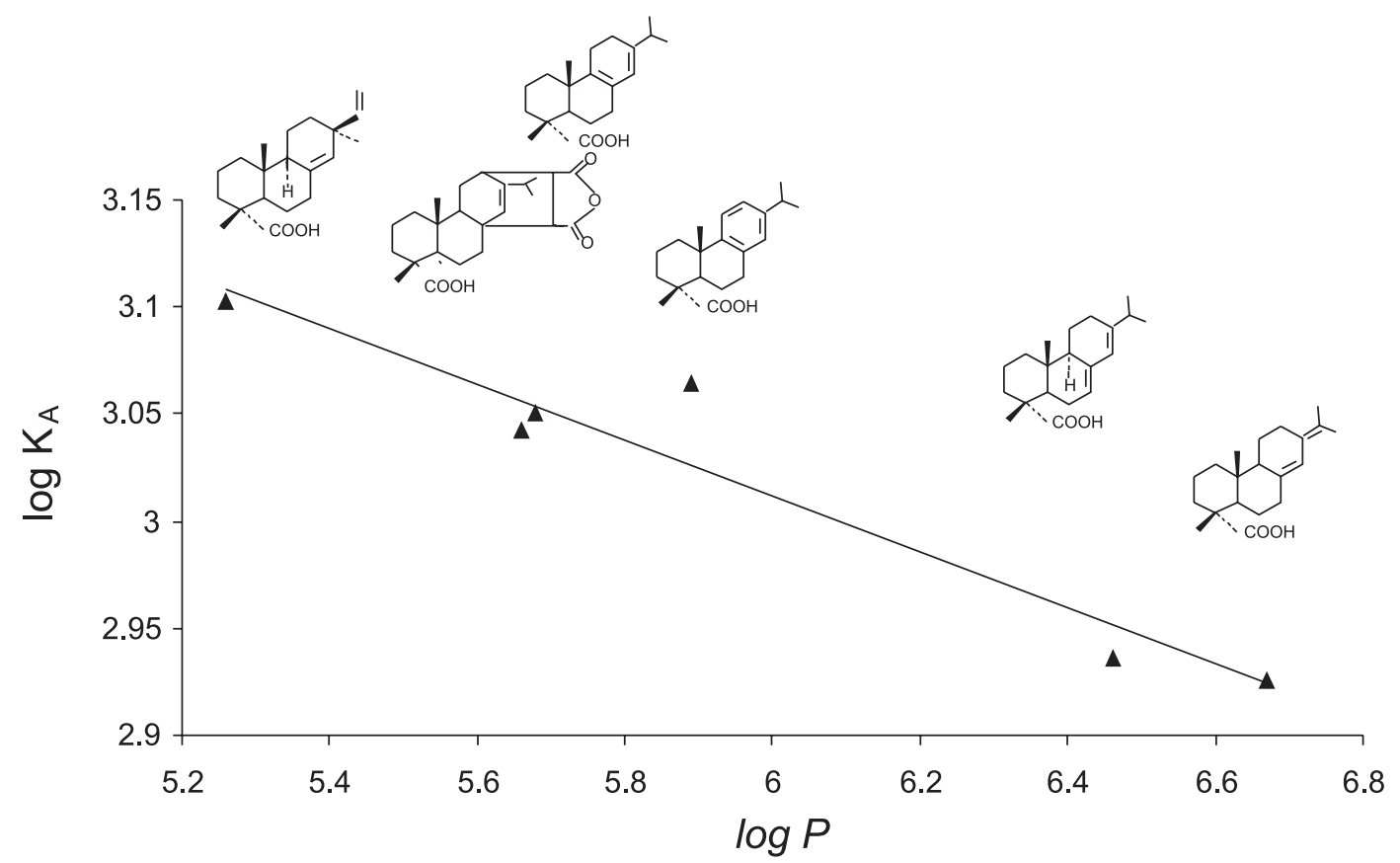

Fig. 5. The plot of $\log K_{A} v s \log P$ for CA complexes with pimaric 1 , maleopimaric 2 , palustric 3 , dehydroabietic 4 , abietic 5 , neoabietic 6 acids (the relationship described this correlation is: $y=-0.1307 x+3.7964 ; r=0.96$ ).

of the upper rim imino group. The carboxylic groups of dehydroabietic, palustric and maleopimaric acids form hydrogen bonds with oxygen atoms on the CA lower rim (Fig. 6B, 6E, 6F).

\section{Experimental Part}

The methanol and acetonitrile were obtained from Acros Organics (Thermo Fisher Scientific, New Jersey - USA), and resin acids were obtained from Sig-
ma-Aldrich (Sigma-Aldrich Corporation, Sigma-Aldrich Box 14508, St. Louis Missouri, 63178, USA). CR was synthesized by the method [28] and CA - by the method [29].

\section{RP HPLC analysis}

The chromatographic experiment was performed on a Hitachi liquid chromatographic system (Hitachi, Ltd., Tokyo, Japan) with an UV detector $(\lambda=254 \mathrm{~nm})$. The column ( $250 \times 4.6 \mathrm{~mm}$ i.d.) was LiChrosorb RP 18

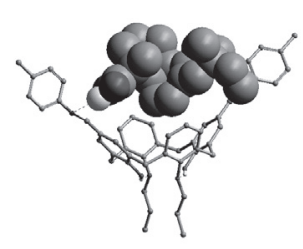

A

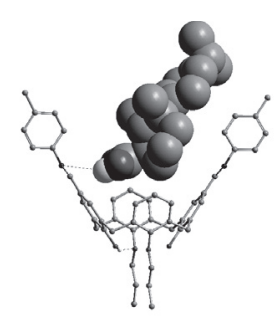

D

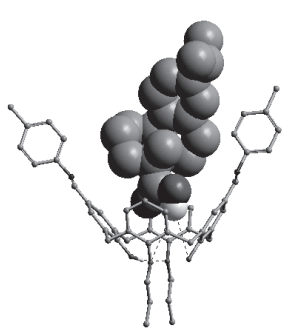

B

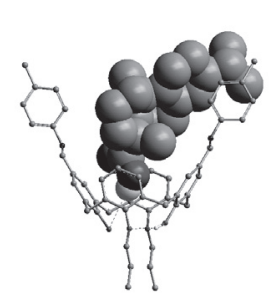

E

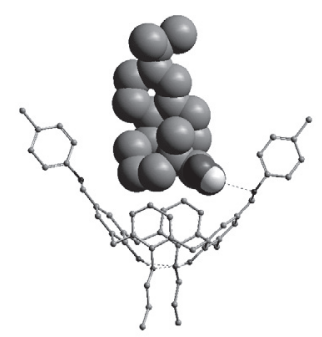

C

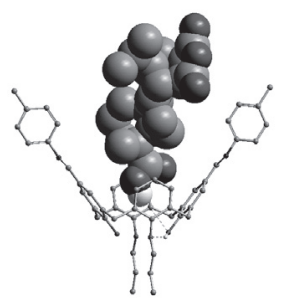

$\mathrm{F}$

Fig. 6. Energy minimized structures of CA complexes with pimaric (A), dehydroabietic (B), abietic (C), neoabietic (D), palustric $(E)$ and maleopimaric $(F)$ acids. 
(Merck, Germany). The mobile phases based on CR and CA ( $\mathrm{C}=0.01 \mathrm{mM}$ ) were prepared by dissolving calixarenes in $\mathrm{MeOH} / \mathrm{H}_{2} \mathrm{O} /$ formic acid (75/25/0.01, v/v) (phase $\mathrm{A}$ for $\mathbf{C R}$ ) and $\mathrm{MeCN} / \mathrm{H}_{2} \mathrm{O} /$ formic acid (86/14/ $0.01, \mathrm{v} / \mathrm{v}$ ) (phase B for CA), respectively. The sample injected was $20 \mu \mathrm{L}$. All chromatograms were obtained at $22^{\circ} \mathrm{C}$. All measurements were performed in triplicate. The phases A and B were used as blank ones for $\mathbf{C R}$ and $\mathbf{C A}$ analysis, respectively.

The binding constants of $\mathbf{C R}$ and $\mathbf{C A}$ complexes with acids 1-6 were calculated by the RP HPLC method described in [30] by changing of the retention factor $k^{\prime}$ values for acids during complexation.

Determination of the $\log P$ values of resin acids and molecular modelling

The values of $\log P$ of acids 1-6 were calculated from the equation: $\log P=7.746 \cdot(\log k)$ where coefficient 7.746 was the ratio of the experimental value of $\log P$ of abietic acid 6.46 [31] to $\log k^{\prime}$ value of abietic acid 0.834 determined by the RP HPLC method in this work.
Molecular modelling of calixarene complexes with acids 1-6 were carried out using Hyper Chem 8.0 (PM3) [32]. The structures were calculated by the semi-empirical method PM3. The RMS (standard deviation of the word root mean square) gradient was equal to $0.01 \mathrm{kcal} / \mathrm{A} \mathrm{mol}$.

\section{Conclusions}

Using the RP HPLC method it has been shown that the cone-shaped calix[4]arene and calix[4]resorcinarene functionalized at the upper rim with proton accepting imino groups or phosphoryl groups, respectively, form strong Host-Guest inclusion complexes $\left(\mathrm{K}_{A} 395-1268 \mathrm{M}^{-1}\right)$ with a series of diterpenoid (resin) acids in water-containing solutions. The complexes are stabilized by the hydrophobic Host-Guest interactions and hydrogen bonds of the Guest $\mathrm{COOH}$ groups with basic nitrogen atoms or oxygen atoms of the Host molecule. Calixarenes similar to cyclodextrins can be considered as promising Host molecules in design of drug delivery systems for biologically active resin acids.

\section{References}

1. Feliciano A. S., Gordaliza M., Salinero M. A., Corral J. M. M. Planta Medica, 1993, Vol. 59, pp.485-490.

2. Roh S. S., Park M.-K., Kim Y., Journal of Health Science, 2010, Vol. 56, pp.451-455.

3. Svikle D. Ya., Prokule A. Ya., Shuster Ya., Veselov I. A. Pharmaceutical Chemistry Journal, 1978, Vol. 12, pp.617-620.

4. Tretyakova E. V., Smirnova I. E., Salimova E. V., Odinokov V. N. Bioorganic \& Medicinal Chemistry, 2015, Vol. 23, pp.6535-6774.

5. Yan F., Mosier P. D., Westkaemper R. B., Stewart J., Zjawiony J. K., Vortherms T. A., Sheffler D. J, Roth B. L. Biochemistry, 2005 , Vol. 44, pp.8643-8651.

6. Gonza'lez M. A., Correa-Royero J., Agudelo L., Mesa A., Betancur-Galvis L. European Journal of Medicinal Chemistry, 2009 , Vol. 44, pp.2468-2472.

7. Nicholson R. A., Lees G., Zheng J., Verdon B. British Journal of Pharmacology, 1999, Vol. 126, pp.1123-1132.

8. Ulusu N. N., Ercil D., Sakar M. K., Tezcan E. F. Phytotherapy research, 2002, Vol. 16, pp.88-90.

9. Trandafirescu C., Antal D., Soica C., Zupko I., Minorics R., Ambrus R., Borcan F., Oprean C., Danciu C., Avram S., Dehelean C., Nita S., Vlaia L. Review Chemistry (Bucharest), 2014, Vol. 65, pp.1163-1167.

10. Fernández M. A., Tornos M. P., García M. D., de las Heras B., Villar A. M., Sáenz M. T. Journal of Pharmacy and Pharmacology, 2001, Vol. 53, pp.867-72.

11. Spessard G. O., Matthews D. R., Nelson M. D., Rajtora T. C., Fossum M. J., Giannini J. L. Journal of Agricultural and Food Chemistry, 1995, Vol. 43, pp.1690-1694.

12. Talevi A., Cravero M. S., Castro E. A., Bruno-Blanch L. E. Bioorganic and Medicinal Chemistry, 2007, Vol. 17, pp.1684-1690.

13. Agudelo-Gómez L. S., Betancur-Galvis L. A., González M. A. Pharmacology On Line, 2012, Vol. 1, pp.36-42.

14. Svikle D. Ya., Prokule A. Ya., Shuster Ya., Veselov I. A. Pharmaceutical Chemistry Journal, 1978, Vol. 12, pp.617-620.

15. Flekhter O. B., Tret'yakova E. V., Makara N. S., Gabdrakhmanova S. F., Baschenko N. Zh., Galin F. Z., Zarudii F. S., Tolstikov G. A. Pharmaceutical Chemistry Journal, 2003, Vol. 37, pp.142-144.

16. Wang H. M., Soica C. M., Wenz G. Natural Products Communications, 2012, Vol. 7, pp.289-291.

17. Cerga (Vlaston) O., Borcan F., Bernad E., Popovici I. Journal of Agroalimentary Processes and Technologies, 2012, Vol. 18, pp.130-135.

18. Şoica C. M., Dehelean C. A., Peev C. I., Coneac G., Gruia A. T. Farmacia, 2008, LIV 2, pp.182-190.

19. Gutsche C. D. Calixarenes Revisited. Royal Society of Chemistry, Cambridge, UK, 1998.

20. Sansone F., Segura M., Ungaro R. Calixarenes in bioorganic and biomimetic chemistry. In: M.-Z. Asfari, V. Böhmer, J. Harrowfield, J. Vicens (eds.), Calixarenes 2001. Kluwer Academic Publishers, Dordrecht, 2001, pp.496-512.

21. Rodik R. V., Boyko V. I., Kalchenko V. I. Current Medicinal Chemistry, 2009, Vol. 16, pp.1630-1655.

22. Da Silva E., Lazar A. N., Coleman A. W. Journal of Drug Delivery Science and Technology, 2004, Vol. 14, pp.3-20.

23. Kalchenko O. I., Solovyov A. V., Lipkowski J., Kalchenko V. I. Journal of Inclusion Phenomena and Macrocyclic Chemistry, 1999, Vol. 34, pp.259-266.

24. Kalchenko O. I., Solovyov A. V., Lipkowski J., Kalchenko V. I. Journal of Chemical Research (S), 1999, pp.60-61.

25. Kalchenko O. I., Cherenok S. O., Kalchenko V. I., Solovyov A. V., Gorbatchuk V. V.Journal of Organic and Pharmaceutical Chemistry, 2013, Vol. 11, pp.3-8.

26. Kalchenko O. I., Cherenok S. O., Solovyov A. V., Kalchenko V. I. Supramolecular Chemistry, 2014, Vol. 26, pp.409-413.

27. Kalchenko O. I., Solovyov A. V., Cherenok S. A., Starodub N. F., Kalchenko V. I. Journal of Inclusion Phenomena and Macrocyclic Chemistry, 2003, Vol. 46, pp.19-25.

28. Kalchenko V. I., Rudkevich D. M., Shivanyuk A. N., Tsimbal I. F., Pirozhenko V. V., Markovsky L. N. Russian Journal of General Chemistry, 1994, Vol. 64, pp.731-742. 29. Markovsky L. N., Kalchenko V. I., Solovyov A. V., Finocchiaro P., Failla S., Atamas L. I., Consiglio G., Tsymbal I. F. Anales de Quimica, 1998 , Vol. 94 , pp.164-170.

30. Lipkowski J., Kalchenko O. I., Slowikowska J., Kalchenko V. I., Lukin O. V., Markovsky L. N., Nowakowski R. Journal of Physical Organic Chemistry, 1998, Vol. 11, pp.426-435.

31. Meylan W. M., Howard P. H. Journal of Pharmaceutical Sciences, 1995, Vol. 84, pp.83-92.

32. http://www.hyper.com/Download/AllDownloads/tabid/470/Default.aspx.

Надійшла до редакції 01.03.2016 p.

\section{Acknowledgement}

This work is supported by the State Fund for Fundamental Research of Ukraine. The work of V.V. Gorbatchuk was performed according to the Russian Government Program of Competitive Growth of the Kazan Federal University. 